
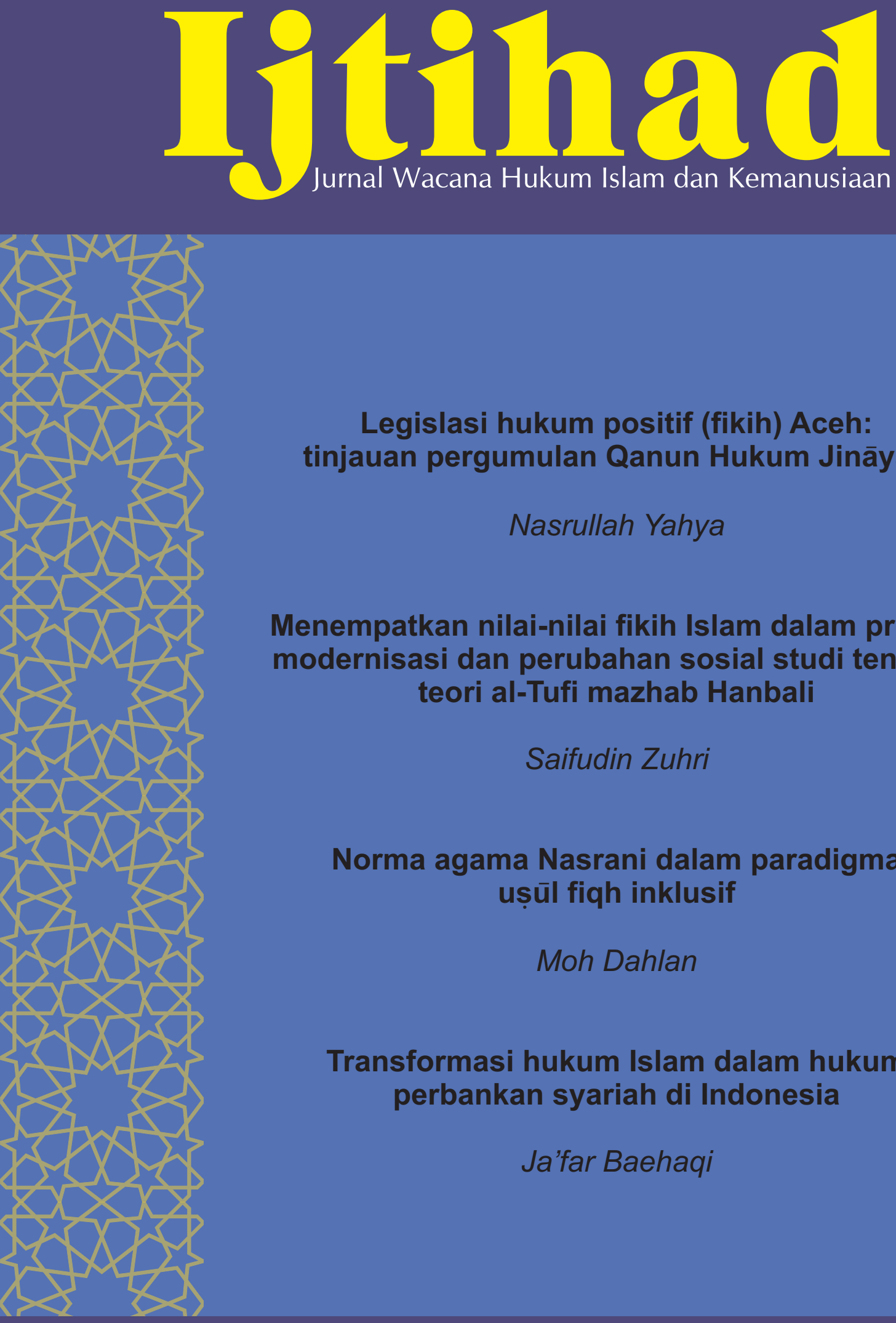

Legislasi hukum positif (fikih) Aceh: tinjauan pergumulan Qanun Hukum Jināyāh

\author{
Nasrullah Yahya
}

Menempatkan nilai-nilai fikih Islam dalam proses modernisasi dan perubahan sosial studi tentang teori al-Tufi mazhab Hanbali

Saifudin Zuhri

Norma agama Nasrani dalam paradigma ușūl fiqh inklusif

Moh Dahlan

Transformasi hukum Islam dalam hukum perbankan syariah di Indonesia

Ja'far Baehaqi 


\section{Ijtihad \\ Vol. 14, No. 2, Desember 2014}

\section{Daftar isi}

Legislasi hukum positif (fikih) Aceh: tinjauan pergumulan Qanun Hukum Jināyāh

Nasrullab Yabya • 149-166

Menempatkan nilai-nilai fikih Islam dalam proses modernisasi dan perubahan sosial studi tentang teori al-Tufi mazhab Hanbali

Saifudin Zubri • 167-187

Norma agama Nasrani dalam paradigma uṣūl fiqh inklusif

Mob Dablan • 189-209

Transformasi hukum Islam dalam hukum perbankan syariah di Indonesia Ja'far Baehaqi • 211-230

Akar, posisi, dan aplikasi adat dalam hukum

Abwan Fanani - 231-250

Bayang-bayang teori keagenan pada produk pembiayaan perbankan syariah Misnen Ardiansyah • 251-269

Dimensi politik hukum dalam perkembangan ekonomi Islam di Indonesia Bambang Iswanto • 271-284

Book Review:

Kritik otoritas pemaknaan hadis menuju masyarakat Islam berkemajuan Mubammad Irfan Helmy • 285-297 



\title{
Kritik otoritas pemaknaan hadis menuju masyarakat Islam berkemajuan
}

\author{
Muhammad Irfan Helmy \\ Institut Agama Islam Negeri (LAIN) Salatiga \\ Jl. Tentara Pelajar No. 2 Salatiga 50721 Jawa Tengab \\ E-mail:mihelmy@gmail.com \\ Judul : Jināyah Qabilab Haddathanā \\ Penulis : Jamal Al-Banna \\ Penerbit : Dar el-Shourouk Cairo \\ Tahun Terbit : 2010 \\ Tebal : $101 \mathrm{hlm}$.
}

\section{Pendahuluan}

Sepeninggal Rasulullah Saw. perdebatan seputar keabsahan hadis sebagai sumber hukum Islam tampaknya tidak akan menemukan akhir. Bahkan, kecenderungan dalam hal ini mengarah kepada semakin tingginya intensitas perdebatan seputar keabsahan dan keotentikan hadis. Ini tidak hanya terjadi di kalangan ulama hadis yang muslim, tetapi juga di kalangan orientalis Barat non muslim yang menaruh perhatian kepada studi hadis.

Di kalangan cendekiawan muslim, salah satu perdebatan sengit seputar keabsahan hadis, terjadi antara Musthafa al-Siba’i dan Ahmad Amin. Perdebatan ini berupa sanggahan Musthafa al-Siba'i terhadap pemikiran Ahmad Amin mengenai hadis dalam karyanya Fajr al-Islam. Sanggahan Musthafa al-Siba'i sendiri kemudian di bukukan dalam karyanya al-Sunnah wa Makēanatubä fi al-Tashrì al-Istamì (Brown, 2000: 146-147). 
ljtihad, Jurnal Wacana Hukum Islam dan Kemanusiaan, Volume 14, No. 2, Desember 2014: 285-297

Perdebatan sengit lain seputar persoalan hadis juga terjadi setelah munculnya buku karangan Abu Rayyah yang berjudul Adewā' an al-Sunnah al-Mụ̣ammadiyah dan Abü Hurairah Shaykh al-Midirah yang isinya bernada mendeskriditkan ahli hadis. Kedua buku ini kemudian mendorong kepada lahirnya karya seputar ilmu hadis seperti Ușul al-Hạadis dan al-Sunnah Qabl al-Tadwin karangan Muhammad Ajjaj al-Khatib, al-Sunnah wa Makanätuhä fi al-Tashrì' alIs lami karangan Mushtafa al-Siba’i dan Difá an al-Sunnab karangan Muhammad Abu Syahbah. Selain itu, perdebatan juga terjadi setelah Muhammad al-Ghazali menerbitkan bukunya alSunnah al-Nabawiyyah Bain abl al-Fiqh wa Abl al-Hadis. Pemikiran al-Ghazali tentang hadis dalam buku ini kemudian menuai bantahan diantaranya adalah buku Kashf Manqif al-Gazăăi min al-Sunnah wa Ablibā wa Naqd ba'di Aräïbi karangan Rabi bin Hadi al-Madkhali. Dalam bukunya al-Ghazali berusaha memperbaiki kecenderungan umum di kalangan pakar muslim kontemporer yang menyerang faqih besar dengan dalih membela sunnah. Buku ini menggambarkan hasrat al-Ghazali untuk melepaskan diri dari keterpakuan terhadap isnad dan hasrat untuk meneliti matan hadis sesuai dengan metode faqih.

Sementara itu, gugatan lebih dahsyat terhadap keabsahan hadis datang dari kalangan orientalis Barat yang juga mendapat tanggapan dari ulama hadis muslim. Ignaz Goldziher, seorang orientalis asal Hongaria, terkenal dengan kritik-kritiknya yang sangat tajam terhadap hadis. Studi-studi hadis yang dilakukan Goldziher kemudian dijadikan rujukan utama bagi kajian hadis di kalangan orientalis. Hampir tidak ada studi hadis di kalangan orientalis yang tidak menggunakan studi karya Goldziher. Studi Goldziher tentang hadis menjadi "kitab suci" orientalis dalam kajian hadis.

Dalam bukunya itu, Goldziher sampai kepada kesimpulan bahwa bagian terbesar hadis hanyalah hasil perkembangan Islam pada abad pertama dan kedua Hijriyah, baik dalam bidang keagamaan, politik maupun sosial. Bagi Goldziher, mustahil hadis nabi merupakan dokumen Islam yang sudah ada pada masa dini. Hadis nabi hanyalah pengaruh perkembangan Islam pada masa kematangan. (Yaqub, 2000:50) Pernyataan Goldziher ini jelas menjadi bukti keraguannya terhadap otentisitas hadis yang sekian lama telah menjadi keyakinan para ulama hadis.

Kritik Goldziher terhadap hadis yang juga menghenyakkan para ulama hadis adalah pernyataannya bahwa penelitian hadis yang telah dilakukan ulama klasik tidak bisa 
dipertanggungjawabkan secara ilmiah karena kelemahan metodenya. Itu diakibatkan karena ulama lebih banyak terfokus pada kritik sanad dan melupakan kritik matan. Inilah yang kemudian mendorong Goldziher menawarkan metode kritik baru yang hanya terbatas pada kritik matan (Yaqub, 2000:15).

Tidak sampai disitu, Goldziher juga mengkritik para ulama hadis yang selama ini diakui otoritas dan kualitasnya di kalangan ulama hadis klasik. Diantara mereka Ibn Syihab alZuhri. Dalam pandangan Goldziher, al-Zuhri telah membuat hadis yang sanadnya bersambung sampai kepada Nabi saw di bawah tekanan politis Abdul Malik bin Marwan. Dari sini kemudian Goldziher menyatakan bahwa al-Zuhri telah melakukan pemalsuan hadis. Jika demikian, maka hadis tersebut tidak shahih karena hanya merupakan buatan al-Zuhri, bukan sabda Nabi saw walaupun itu terdapat dalam Șahih al-Bukhäri yang diakui otentisitasnya oleh umat Islam. Bahkan, kitab ini diakui sebagai kitab hadis yang paling tinggi tingkatannya dibanding kitab hadis lain (Yaqub, 2000:15).

Adapun Josep Schacht muncul sebagai peneliti hadis dari kalangan orientalis kurang lebih enam puluh tahun setelah terbitnya buku Goldziher. Schacht menerbitkan karya penelitiannya tentang hadis dalam sebuah buku berjudul The Origins of Muhammadan Jurisprudence. Konon, lebih dari sepuluh tahun ia melakukan penelitian hadis. Dan sejak tahun 1950 M buku Schacht ini menjadi "kitab suci" kedua di kalangan orientalis (Yaqub, 2000: 51).

Lewat bukunya yang banyak mendapat pujian dari para orientalis lain, Schacht berpendapat berbeda dengan keyakinan ulama hadis klasik. Dalam analisisnya, hadis telah memainkan peranan yang signifikan dalam pembentukan hukum Islam. Lewat penelusurannya terhadap otentisitas hadis, ia menyimpulkan bahwa hadis nabi telah diformulasikan oleh generasigenerasi belakangan dan tidak ada kaitan sama sekali dengan nabi itu sendiri. Atas dasar ini, maka hukum Islam tidak berasal dari kehidupan Nabi Muhammad saw dan pembentukan hukum Islam sesungguhnya bertitik tolak dari praktek popular dan administrasi Umayyah (Minhaji, 2001:2,33).

Jika Ignaz Goldziher hanya sampai pada tingkat meragukan otentisitas hadis, Schacht justeru sampai pada keyakinan bahwa tidak ada hadis yang sahih terutama hadis-hadis hukum. Bagi Schacht, hadis-hadis yang berhubungan dengan hukum Islam, hanyalah buatan para ulama abad kedua dan ketiga Hijriyah (Juynboll, 1999: 2). 
Dalam kaitan ini, dalam The Origins of Mubammadan Jurisprudence, Schacht menyatakan bahwa pada umumnya, tradisi yang hidup dari mazhab-mazhab fikih klasik, didasarkan sejumlah besar pada penalaran individual terlebih dahulu, kemudian pada tahap kedua dinyatakan berasal dari sahabat, dan hadis-hadis dari nabi sendiri diletakkan ke dalam peredaran oleh para ahli hadis menjelang pertengahan abad kedua Hijriyah. Dalam buku yang sama, Schacht menyimpulkan bahwa tidak akan ditemukan sejumlah besar hadis-hadis hukum dari nabi yang diketahui Malik berasal dari generasi-generasi yang mendahukuinya, yakni pada seperempat kedua dari abad kedua Hijriyah. Dan kita tidak akan menemukan hadis hukum apapun dari nabi yang dapat dianggap otentik (Azami, 2004: 163).

\section{Jamal al-Banna dan tinjaun kritis atas hadis}

Seperti para pengkritik hadis lainnya, Jamal Al-Banna seorang pemikir kontemporer asal Mesir juga menuangkan ide-ide kritisnya tentang hadis dalam karyanya yang berjudul 'Jináyah

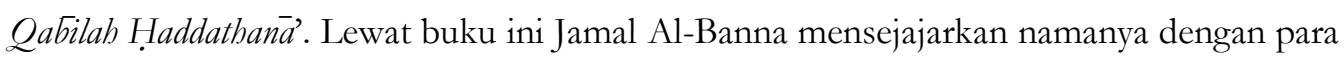
pengkritik hadis sebelumnya.

Menurut Al-Banna karyanya tidak secara langsung mengupas tentang sunnah. Seperti dikemukakan dalam bagian awal buku ini bahwa dalam buku ini tidak ada bahasan yang menyinggung sunnah. Sebagaimana diketahui bahwa sunnah adalah praktek atau cara. Bagi Al-Banna sunnah juga merupakan jalan dan perjalanan yang mempunyai karakter yang sangat praktis sehingga sangat berbeda dengan hadis yang mempunyai karakter verbal atau lisan (hlm.7).

Dalam buku ini juga tidak ada bahasan yang menyinggung hadis. Bahasan-bahasan dalam buku ini semuanya terkait dengan satu kelompok yang mengokohkan dirinya dalam pengumpulan hadis-hadis dan meninsbatkannya kepada Rasulullah Saw. Dalam kelompok tersebut terdapat karakter-karakter yang menjadikan mereka sebagai kelompok independen dengan karakter yang khusus sehingga dianggap sebagai salah satu gerakan yang paling memengaruhi terhadap dinamika pemikiran Islam (hlm. 7).

Disamping itu, kelompok ini juga mengklim diri sebagai kelompok yang temasuk dalam kelompok yang selamat dari tujuh puluh tiga kelompok yang ada dalam umat Islam dengan alasan karena kelompok ini membawa nama Rasul dan mengakui telah meriwayatkan hadis 
beliau. Selain itu, banyak faktor lain yang menjadikan mereka sebagai kelompok terkuat dalam komunitas muslim. Kelompok ini sangat berpengaruh dalam kehidupan umat muslim dibanding dengan kelompok-kelompok lain dalam Islam. Akan tetapi sayangnya, kelompokkelompok ini menimbulkan efek buruk bagi Islam dan secara lebih khusus mencemari pola pemikiran Islam dalam masyarakat muslim (hlm.7).

Kelompok tersebut gencar menyebut tokoh-tokoh pemikiran Islam modern dengan sebutan para pengingkar Sunnah bahkan ada di antara anggota kelompok mereka yang menulis sebuah karya dengan menyebut jelas satu-satu persatu mereka yang dianggap sebagai para pengingkar sunnah (hlm.8).

Lewat buku ini, Al-Banna mengungkap kemunculan sebuah kelompok yang disebut dengan qabilah haddathaña sejak masa-masa awal dalam kehidupan Rasulullah Saw dan Khulafa al-rāshidun dimana kelompok tersebut belum tampak jelas kemunculan dan keberadaannya kemudian perkembangan yang terjadi pada masa khilafah Islam di Madinah dilanjutkan dengan perkembangan pada masa Dinasti Islam yang memberikan andil adanya pemalsuan hadis bahkan terkesan menjadi suatu keharusan yang dalam tahap berikutnya memunculkan kelompok yang disebut dengan qabilah haddathana (hlm.8)

\section{Penulisan hadis}

Al-Khatib al-Bagdadi mencatat riwayat berkenaan dengan praktek sahabat Abu Bakar dalam penulisan hadis. Diriwayatkan bahwa Abu Bakar menuliskan untuk sahabat Anas bin Malik pesan Nabi Saw yang berisi hukum-hukum zakat yang diwajiban atas kaum muslimin. Diriwayatkan pula bahwa sahabat Umar bin Khattab menyampaikan pernyataan yang berisi perintah agar mengikat ilmu dengan tulisan. Di samping itu, ada pula riwayat yang menceritakan bahwa sahabat Ali bin Abi Talib berkhutbah di atas mimbar dan menyatakan bahwa selain al-Qur'an dirinya juga mempunyai sebuah șậifah yang biasa dibacanya berisi tentang hukumhukum zakat yang diterima dari Nabi Saw. (Azami, 2000: 112).

Para sahabat yang melakukan kegiatan penulisan hadis tidak berarti mereka tidak mengetahui hadis yang berisi larangan penulisan selain al-Qur'an. Bagi sahabat seperti Abu Bakar, Umar bin Khattab dan Ali bin Abi Talib yang selalu mengikuti aktifitas Nabi Saw. hadis larangan penulisan tersebut juga menjadi bagian dari pesan yang mereka terima dari 
Nabi Saw. Hanya saja, seiring dengan perkembangan situasi mereka harus melakukan pemaknaan terhadap hadis-hadis yang berisi larangan penulisan dan hadis-hadis yang berisi persetujuan Nabi Saw terhadap penulisan hadis.

Statemen di atas tentang fakta terjadinya penulisan hadis, dalam pandangan al-Banna tidak begitu saja dapat diterima. Bagi al-Banna hadis-hadis yang dianggap șậį̣ dalam hal penulisan hadis sesungguhnya tidak lebih dari sekadar pengecualian dari prinsip umum dan hanya berlaku untuk satu orang saja. Oleh karena itu, tidak dapat dianggap sebagai hadis yang merekomendasikan penulisan hadis (hlm.11). Adapun hadis-hadis yang berbicara tentang larangan penulisan hadis lebih dapat dipertanggungjawabkan kebenarannya dibanding hadishadis yang berisi perintah penulisan hadis (hlm.12).

Dari banyak data yang berbicara tentang penulisan hadis, yang berawal dari masa Nabi Saw kemudian diikuti masa Khulafa al-Räashidūn dan Masa Sahabat dan berlanjut pada masa Tabi'in, jelaslah bahwa larangan penulisan hadis dan perintah menyedikitkan periwayatan hadis adalah sebuah prinsip yang disepakati. Adapun sebab yang melatarbelakanginya adalah kekhawatiran terhadap hadis yang dapat menggantikan posisi al-Qur'an dan juga karena kekhawatiran akan terjadinya lupa pada periwayat hadis yang dapat mengakibatkan kedustaan yang tidak diharapkan. Hal ini bahkan sangat direkomendasikan dengan banyaknya riwayat tentang hal ini terlebih jika kita berpikir tentang apa yang mungkin dilakukan oleh musuhmusuh Islam dari golongan Munafiq dan Yahudi (hlm.19).

\section{Hadis Mursal}

Dalam sejarah mustalah al-hadis, hadis mursal adalah hasil rumusan al-Syafi'i Selain teori tentang hadis ahäd, al-Syafi'i juga merumuskan kaidah-kaidah tentang hadis mursal. Bagi alSyafi'i meneliti hadis mursal sangat erat kaitannya dengan kebersambungan sanad hadis. Dari kajian terhadap kebersambungan sanad ini, al-Syafi'i juga merumuskan kaidah tentang hadis munqati.

Menurut al-Syafi'i hadis mursal adalah perkataan rawì yang bukan dari golongan sahabat, baik itu tabi'in atau generasi setelahnya, yang menyandarkan hadis langsung kepada Nabi Saw., tanpa menyebutkan nama sahabat yang menjadi penyambung antara Nabi Saw. dan dirinya. Definisi hadis mursal seperti ini lebih umum daripada definisi hadis mursal dalam 
istilah para ahli hadis.

Al-Syafi'i mengklasifikasikan hadis mursal menjadi dua kategori. Pertama, hadis mursal dari tabi'in senior (mursal kibär at-tabīin), mereka adalah orang-orang yang paling banyak meriwayatkan hadis dari para sahabat. Kedua, hadis mursal dari tabi'in junior (mursal sigar altábi'in), mereka adalah orang-orang yang paling banyak meriwayatkan hadis dari para tabi'in senior.

Dalam konteks ini, Al-Banna menyatakan perlunya dilakukan tinjauan kritis terhadap istilah yang disebut dengan hadis mursal dan mudallas. Misalnya seorang tabi’i meriwayatkan hadis dari Rasulullah Saw tanpa menyambungkan sanadnya kepada sahabat yang langsung menerima dari Rasulullah; atau ada seorang sahabat yang meriwayatkan hadis yang belum pernah didengarnya secara utuh dari Rasulullah akan tetapi dia menerimanya dari sahabat sejawatnya yang mendengar langsung dari Nabi Saw. Ini adalah model hadis dengan sanad mursal yang perlu dikaji secara lebih dalam dan kritis. Para ahli hadis meskipun mereka berbeda pendapat dan argumentasi dalam menerima hadis mursal, mereka tetap menerima hadis yang tergolong hadis mursal sahabat dan seolah ini menjadi konsensus para ahli hadis (hlm.58).

Bagi al-Banna, Fenomena hadis mursal sesungguhnya dapat dipahami bahwa kebersambungan para periwayat hadis pada fase sebelum kodifikasi hadis adalah hal yang belum menjadi perhatian untuk dikaji ulang. Dan fakta yang dapat diungkap adalah bahwa periwayatan hanya terjadi antara seorang periwayat seperti al-Bukhari dengan gurunya seperti al-Humaidi. Adapun kebersambungan periwayatan antara periwayat satu sama lain setelah al-Humaidi sampai level periwayat hadis yang langsung menerima hadis dari Nabi Saw, semuanya itu belum dapat dibuktikan. Sementara ini, para ulama hadis muta'akhirūn memastikan suatu fakta selama belum ada bukti ketidakbersambungan antara dua orang periwayat hadis seperti wafatnya seorang perawi sebelum lahirnya perawi yang lainnya (hlm.58).

Berdasarkan fakta ini, maka dapat dikatakan bahwa sebagian besar hadis yang sampai kepada kita adalah hadis mursal tanpa kita sadari. Sebenarnya, kesalahan tidak terdapat pada kemursalan yang bercampur kedustaan sebagaimana ditangarai oleh para ahli hadis sebab kedustaan itu sangat jauh dari kehidupan sahabat. Akan tetapi, yang menjadi persoalan adalah 
proses transmisi hadis dari orang per orang terutama ketika hal itu terjadi secara berulangulang dan itu jelas terbukti terjadi berkali-kali sebelum adanya pembukuan hadis. Hal itu jelas akan menimbulkan semacam penyimpangan yang dapat merubah makna yang dimaksud dari hadis akibat dari kekeliruan dalam mendengar dan memahami hadis terlebih dengan adanya kebolehan periwayatan hadis secara makna (hlm.58).

Tidak diragukan lagi bahwa ribuan karya yang memuat hadis-hadis itu tidak pernah sampai kepada kita dan sangat mungkin diduga bahwa pendapat-pendapat tentang banyaknya hadis yang jumlahnya mencapai ratusan ribu itu pada dasarnya hanyalah anggapan yang jauh dari kebenaran dan keakuratan. Adapun sedikit hadis yang sampai kepada kita itu pun banyak yang menimbulkan keraguan. Upaya untuk memahami hadis yang diduga meragukan itu sebenarnya sudah dilakukan oleh dua orang ahli seperti Ibn Qutaibah dalam karyanya Ta'wil Mukbtalif al-hadis yang mencoba mengurai hadis yang menyimpan makna kontradiktif. Hal yang sama juga dilakukan oleh Muhammad Abu Syahbah dalam karyanya al-Isräiliyä wa al-Maudu'at fi kutub al-Tafsir yang mencoba menanggapi hadis-hadis yang dikritik oleh Mahmud Abu Rayyah dalam buku Adwa ala al-Sunnah al-nabawawiyyah. Akan tetapi sayangnya upaya kedua tokoh ini belum berhasil bahkan menguatkan anggapan bahwa keduanya lebih percaya kepada orang dan sanad hadis ketimbang makna dan matan hadis tersebut (hlm.68).

\section{Kitab-kitab hadis}

Pandangan yang mendominasi kebanyakan kaum muslim adalah bahwa para ahli hadis telah mengerahkan segenap kemampuannya dan berkontribusi besar dalam merumuskan ilmu hadis dan segala yang berkaitan dengan hadis seperti ilmu riwayat hadis dan ilmu dirayat hadis. Mereka juga telah sampai kepada metode jarḅ wa ta'dil dan menyusun indeks para periwayat hadis dan hadis-hadis Nabi. Disamping itu mereka juga telah menciptakan metode yang tidak pernah ada dalam agama-agama lain selain Islam yang dengan itu mereka bertujuan mendekatkan diri kepada Allah dan menjaga Sunnah Nabi Saw. Mereka menghabiskan umur mereka dalam berkhidmah untuk sunnah dari generasi ke generasi yang menggambarkan keberlangsungan dimana generasi yang setelahnya memberikan penambahan dan penyempurnaan terhadap karya-karya pendahulunya. Semua itu secara tidak disadari telah memunculkan kultus terhadap para pendahulu mereka sehingga terkesan 
Kritik otoritas pemaknaan hadis menuju masyarakat Islam berkemajuan (Muhammad Irfan Helmy)

bersumpah dengan nama Imam al-Bukhari seperti bersumpah dengan nama Allah dan alQur'an (hlm.71).

Pandangan di atas bagi al-Banna tidak semuanya keliru. Hanya saja perlu diungkap dimensi lain dari kehidupan para ahli hadis tersebut. Bagi Al-banna, tidak diragukan lagi bahwa kerja para ahli hadis memang sangat perlu diapresiasi. Akan tetapi satu hal yang perlu diperhatikan juga adalah bahwa permasalahan-permasalahan yang berlangsung seputar kehidupan manusia itu sangat kompleks dan memiliki berbagai macam dimensi. Hal yang sama juga terjadi pada setiap individu yang bisa juga dipengaruhi oleh faktor-faktor yang menekannya dalam melakukan aktifitas (hlm.71).

Menurut al-Banna, tidaklah bisa diterima secara logis apa yang terjadi pada para ahli hadis yang menghimpun ratusan ribu hadis karena jika dihitung untuk sekedar melafalkan lima ratus ribu hadis misalnya, itu memerlukan semua umur mereka sehingga jika untuk melafalkan satu hadis saja memerlukan satu menit, maka tidak ada yang mereka lakukan dalam hidup mereka kecuali membacakan hadis. Disamping itu kita juga mengetahui bahwa hidup Nabi Saw. sebagai Rasul yang selama 23 tahun itu dilingkupi oleh peristiwa-peristiwa, peperangan-peperangan dan kondisi-kondisi lain yang penuh dengan tekanan (hlm.71).

\section{Kekeliruan-kekeliruan Qabillab Ḥaddathanā}

Al-banna mencatat lima kekeliruan kelompok yang disebutnya dengan qabilah haddathana dalam merumuskan pemikiran keagamaan. Pertama, tentang akidah. Dalam pemaknaan terhadap akidah, kelompok ini dapat kita katakan sebagai Wabhabi. Kelompok ini memaknai akidah secara detil dan mencoba mengungkap rahasia-rahasianya dan apa yang tersembunyi dalam akidah itu. Mereka sampai kepada kesimpulan bahwa ada beberapa perkara yang dapat dipahami secara sederhana sementara pada saat yang sama hal itu mengandung konsep syirik akbar dan syirik asgar. Yang pertama dapat mengeluarkan pelakunya dari agamanya dan yang kedua dapat menjadikan iman pelakunya berada dalam kondisi kritis dan berbahaya. Konsep akidah seperti ini harus diketahui oleh setiap individu dan wajib mengimaninya. Siapa saja yang menyalahinya maka dia telah kafir dan siapa yang mengamalkan penyelewengan itu maka berhak di beri label kafir (hlm.81). 
Kelompok ini menawarkan konsep akidah seperti yang diringkas oleh Rasul bahwa iman adalah yakin percaya kepada Allah, para Rasul, para malaikat, kitab-kitab Allah, hari akhir dan qadar Allah yang baik dan yang buruk. Mereka juga membawa konsep bahwa akidah adalah melihat Allah di Akhirat sedangkan dalam al-Qur'an Allah sama sekali tidak bisa dijangkau oleh penglihatan manusia (hlm.88).

Bagi Al-Banna, dalam memahami akidah yang dibawa Rasul seharusnya bisa dengan pemahaman yang lebih baik. Jika sebagian orang salah atau keliru dalam memahami akidah maka tidak begitu saja langsung dikeluarkan dari keimanan karena sesuatu yang lahir akibat kesalahan dan kekeliruan itu tidak sampai kepada derajat meningkari dan menafikan. Pada titik ini, dia perlu dipahamkan secara lebih rinci tentang akidah yang sebenarnya (hlm.88).

Kedua, tentang al-Qur'an. Kelompok ini melakukan kekeliruan terhadap al-Qur'an ketika mereka mengatakan bahwa ibn Abbas adalah adalah penafsir terhebat sehingga diberi gelar hibr al-IsTam dan Turjumān al-Qur'an padahal jika melihat pendapat yang dilontarkan para tokoh dalam karya Ibn Abbas banyak riwayat yang lemah bahkan palsu seperti yang dilontarkan oleh Muhammad Rasyid Ridha (hlm.88).

Kekeliruan lain yang dilakukan oleh kelompok ini adalah ketika membolehkan sunnah untuk menasakh al-Qur'an dengan alasan bahwa sunnah juga merupakan wahyu bahkan ketika al-Syafii menolak prinsip itu para ulama muta'akbirun tidak sependapat dengan AlSyafi'i dan melihat pendapat al-Syafii itu sebuah kesalahan besar. Ada seorang ulama yang banyak merujuk kepada al-Syafi'i ketika mengetahuai pendapat al-Syafi'i tentang prinsip ini dia berkomentar bahwa al-Syafi'i memang tokoh besar tapi kebenaran itu jauh lebih besar daripada al-Syafii (hlm.90). Selain hal di atas, kelompok ini juga banyak menggunakan riwayatriwayat hadis yang secara tidak disadari justeru mencemari kemuliaan al-Qur'an (hlm.91).

Dalam konteks ini, perlu kiranya mengelaborasi pemikiran al-Syafi'i tentang kesejajaran al-Qur'an dan hadis yang kemudian mempengaruhi pemikirannya tentang konsep nask $h$ dalam hadis. Dalam pandangan al-Syafi'i, hadis hanya dapat dinask $h$ dengan hadis. Hadis juga hanya dapat menask h hadis (al-Syafi'i, hlm. 108). Dengan demikian, hadis tidak dapat menaskh ketentuan al-Qur'an meskipun hadis tersebut mempunyai derajat mutawatir. Hadis hanya dapat menerangkan mana ayat-ayat yang masuk ke dalam kategori ayat-ayat mansukkhah. Begitu juga al-Qur'an tidak dapat menaskh hadis. 
Pada dasarnya, al-Syafi'i tidak menolak adanya naskh dalam hukum Islam, baik dalam alQur'an maupun hadis. Namun demikian, al-Syäfi'i membatasi bahwa al-Qur'an hanya dapat menaskh ketentuan yang ada dalam al-Qur'an juga. Hal yang sama juga berlaku pada hadis. Hadis hanya dapat menaskh ketentuan yang ada dalam hadis pula. Artinya, naskh bagi alSyafi'i tidak dibenarkan terjadi dalam bentuk silang di mana al-Qur'an menaskh ketentuan hadis dan sebaliknya hadis menaskh ketentuan al-Qur'an (al-Syafi'i, t.th.: 102).

Menurut al-Syafi'i, hadis tidak dapat menaskh ketentuan dalam al-Qur'an karena hadis secara mutlak harus mengikuti segala ketentuan al-Qur'an. Dalam konteks ini, hadis memberikan penjelasan terhadap kandungan makna al-Qur'an yang masih global. Al-Syafi’i mendasarkan hal ini pada surat Yunus (10): 15. Ayat ini menurut al-Syafi'i merupakan dalil utama tidak adanya naskh al-Qur'an dengan hadis. Allah adalah sumber dari segala perintah, karena itu, otoritas untuk menggantikan, menghapus dan menetapkan hukum hanya berada dalam kekuasaan Allah (al-Syafi'i, t.th.: 102).

Sedangkan penolakan al-Syafi'i terhadap kemungkinan naskh hadis dengan al-Qur'an didasarkan pada pemahaman bahwa yang terkandung dalam hadis adalah berasal dari Allah juga. Karenanya, jika Dia ingin menghapus ketentuan dalam hadis, pasti Allah akan memerintahkan Nabi untuk menggantinya. Dan adanya naskh itu tentu disampaikan Nabi dan tidak hanya berdiam. Dengan kata lain, jika al-Qur'an menaskh suatu hadis, maka pasti diiringi penjelasan dari Nabi. Dengan demikian, hanya hadis yang dapat menaskh hadis lainnya (al-Syafi'i, t.th.: 110).

Berpijak pada pendapat bahwa al-Qur'an tidak bisa dinaskh dengan hadis, al-Syafi'i menolak semua argumentasi dan dalil para penentangnya yang membolehkan menaskh alQur'an dengan hadis. Bagi al-Syafi'i, contoh-contoh yang dikemukakan para penentangnya tidak termasuk kategori menaskh al-Qur'an dengan hadis, melainkan kategori menaskh alQur'an dengan al-Qur'an. Sementara hadis hanya berfungsi sebagai penjelas adanya nask $h$ al-Qur'an dengan al-Qur'an. Dalam hal ditemukan adanya teks hadis yang mengesankan menaskh teks al-Qur'an, bagi al-Syafi'i itu dimasukkan dalam kategori mentakhșiṣ keumuman al-Qur'an (Takbșiṣ 'umūm al-Kitāb) (al-Syafi'i, t.th.: 137-143).

Ketiga, tentang Rasulullah Saw. Kelompok ini telah bersikap keliru terhadap Rasulullah Saw, yang pertama bersifat umum dan yang kedua bersifat khusus. Adapun yang bersifat 
umum yaitu ketika mereka menisbatkan kepada Rasulullah Saw semua hadis-hadis dusta bahkan hadis-hadis yang mengandung khurafat sehingga memberikan poin buruk bagi pemikiran Islam secara keseluruhan. Sedangkan yang bersifat khusus yaitu ketika mereka mempunyai perhatian yang besar terhadap sistem periwayatan hadis dan sanad hadis, tetapi pada saat yang sama mereka juga terperosok dalam pencemaran nama baik Rasulullah Saw. seperti terlihat dalam hadis yang mereka yakini bahwa Rasulullah saw. pernah disihir oleh seorang Yahudi. Ketika hadis ini ditolak oleh Muhammad Abduh karena dianggap bertentangan dengan sifat ishmah Nabi Saw. mereka balik menyerangnya (hlm.96).

Keempat, tentang sosok muslim ideal. Kelompok ini menawarkan sosok muslim dengan gambaran kehidupan muslim yang buruk yang selalu melihat ke belakang dan tidak melihat ke depan dan masa depan. Sosok muslim yang ditawarkan kelompok ini adalah muslim yang hanya mampu mempraktekkan perkara-perkara sederhana dan tidak berusaha untuk meningkatkan kemampuan dengan hal-hal baru. Apa yang dibawa kelompok ini berkaitan dengan prinsip-prinsip hidup muslim adalah prinsip hidup dalam menghadapi masa lalu bukan menghadapi masa depan yang penuh dengan tantangan dan membutuhkan kekuatan diri dalam bersosialisasi dan berinteraksi (hlm. 97-98).

Kelima, tentang Masyarakat. Kelompok ini terbukti telah memberi pengaruh buruk kepada masyarakat. Tidak berlebihan jika dikatakan bahwa mereka telah meruntuhkan masyarakat Islam dan membuat mereka terbelakang. Hal itu karena mereka biasa mengedepankan hadishadis yang merusak pemikiran dan sistem hidup bermasyarakat (98-99).

Pernyataan-pernyataan al-Banna dalam buku ini meski terkesan dekonstruktif sesungguhnya merupakan tawaran sekaligus ajakan untuk menelaah ulang beberapa dimensi tentang hadis. Seperti para pendahulunya yang mengkritik hadis, Al-Banna tampak mengulang beberapa statemen yang sudah dikemukakan para pengkritik hadis sebelumnya. Terlepas dari itu, buku ini cukup berhasil menggungah para pemikir untuk terus melakukan kajian dan penelitian tentang hadis, tidak hanya yang berhubungan dengan dimensi ekternal hadis tetapi juga dimensi internal hadis. Karenanya, buku ini layak menjadi bacaaan para pengkaji studi Islam terutama untuk memperkaya wawasan tentang dinamika studi hadis. 
Kritik otoritas pemaknaan hadis menuju masyarakat Islam berkemajuan (Muhammad Irfan Helmy)

\section{Daftar pustaka}

Azami, M.M. Hadis Nabawi dan Sejarah Kodifikasinya. Jakarta: Pustaka Firdaus, 2000.

Azami, MM. Menguji Keaslian Hadis-Hadis Hukum Sanggahan atas The Origins of Mubammadan Jurisprudence Josep Schacht. Terj. Asrofi Shodri. Jakarta: Pustaka Firdaus, 2004.

Brown, Daniel W. Menyoal Relevansi Sunnah dalam Islam Modern, Terj. Jaziar Radianti dan Entin Sriani Muslim. Bandung: Mizan, 2000.

Juynboll, GHA. Kontroversi Hadis di Mesir (1890-1960) Terj. Ilyas Hasan. Mizan: Bandung, 1999.

Minhaji, Akhmad. Kontroversi Pembentukan Hukum Islam Kontribusi Josep Schacht. Terj. Ali Masrur. Yogyakarta: UII Press, 2001.

Syafi'i al, Muhammad bin Idris. al-Risālah. Tahqīi Ahmad Muhammad Syakir. Beirut: Där al-Kutub al-'Ilmiyyah, t.th.

Yaqub, Ali Mustafa. Islam Masa Kini. Jakarta: Pustaka Firdaus, 2001. 